\title{
Evaluation of the protective effect of Nigella sativa extract and its primary active component thymoquinone against DMBA-induced breast cancer in female rats
}

\author{
Sabah A. A. Linjawi ${ }^{1}$, Wagdy K. B. Khalil², Mahrosa M. Hassanane², Ekram S. Ahmed²
}

${ }^{1}$ Biology Department, College of Science, King Abdulaziz University, Jeddah, Saudi Arabia ${ }^{2}$ Cell Biology Department, National Research Centre, Dokki, Giza, Egypt

Submitted: 19 November 2012

Accepted: 7 January 2013

Arch Med Sci 2015; 11, 1: 220-229

DOI: 10.5114 /aoms.2013.33329

Copyright @ 2015 Termedia \& Banach

\section{Abstract}

Introduction: The historical use of black cumin seed (Nigella sativa) dates back centuries, being embedded in Arabian culture and having a long history of unsurpassed medicinal value with versatility to treat a wide range of ailments. Thymoquinone (TQ) is now known to be the primary active constituent of black cumin seed oil (BCS oil) responsible for its medicinal effects and also showing promise for treatment of cancer.

Material and methods: In the current study, we have studied the effects of TQ and BCS oil on tumor markers (MDA, LDH, ALP and AST), histopathological alterations and the regulation of several genes (Brca1, Brca2, Id-1 and P53 mutation) related to breast cancer in female rats induced by 7,12-dimethylbenz[a]anthracene (DMBA) treatment. Rats received a single dose $(65 \mathrm{mg} / \mathrm{kg}$ b.w.) of DMBA via an intragastric tube to induce breast cancer. Animals that received DMBA were treated orally with $1,5,10 \mathrm{mg} / \mathrm{kg}$ of TQ or BCS oil via an intragastric tube three times per week for 4 months.

Results: We found that TQ and then BCS reduced the rate of tumor markers (levels of MDA and LDH as well as ALP and AST activities), inhibited the histopathological alterations and decreased the expression of the Brca1, Brca2, Id-1 and P53 mutations in mammary tissues of female rats induced by DMBA treatment.

Conclusions: The results suggest that TQ and BCS oil exert a protective effect against breast carcinogens. The antioxidant property of TQ and BCS oil is mediated by their actions and investigating other underlying mechanisms merits further studies.

Key words: rats, breast cancer, Nigella sativa, thymoquinone, gene expression.

\section{Introduction}

Cancer is one of the most formidable health burdens in the world and it remains the second leading cause of death after heart disorders [1]. Breast cancer is one of the most common malignancies affecting women in the Western world today, the lifetime risk being approximately $10 \%$ [2].

In Arabian countries such as Egypt, breast cancer is the most common malignancy among women, representing $18.9 \%$ of total cancer cases among the Egypt National Cancer Institute $(\mathrm{NCl})$ screening of 10,556 patients during the year 2001, with an age-adjusted rate of 49.6 per 100,000 population [3]. Women with diagnosed breast cancer are at

\author{
Corresponding author: \\ Dr. Wagdy K. B. Khalil \\ Cell Biology Department \\ Genetic Engineering \\ and Biotechnology Division \\ National Research Centre (NRC) \\ 33 Bohouth St \\ 12622 Dokki, Giza, Egypt \\ Phone: +2012-27410600 \\ Fax: +202-33370931 \\ E-mail: wkbassaly@gmail.com, \\ wagdykh@yahoo.com
}


a greater risk of experiencing metastases for their entire lifetime.

Breast cancer is both genetically and histopathologically heterogeneous, and the mechanism(s) underlying breast cancer development remains largely unknown. Approximately $5-10 \%$ of breast cancers are of hereditary origin, and two major breast cancer susceptibility genes have been identified to date, BRCA1 and BRCA2. These two genes were initially proposed to be responsible for the majority of inherited breast cancer [4].

In addition, Id helix-loop-helix proteins are negative regulators of basic helix-loop-helix transcription factors [5]. Strong evidence now suggests that the Id family of helix-loop-helix proteins control cellular processes related to tumor progression [6]. Fong et al. [7] found that reducing Id-1 using antisense technology led to significant reductions in breast cancer cell proliferation and invasiveness in vitro and metastasis in vivo in mice [7]. Furthermore, Id-1 overexpression in breast cancer cells was also found to be one of the most significant genes within a gene signature set that is correlated with the propensity of primary human breast cancer cells to metastasize to the lung [8].

Arabian countries are also very rich in historical knowledge in particular about the medicinal use of herbs and spices. Among the most noted is the historical reference to the remarkable use of black cumin seed (Nigella sativa) which dates back to the burial of the Egyptian Pharaoh Tutankhamun. Black cumin was also mentioned in ancient texts by Hippocrates and Dioscorides to treat headaches and toothaches [9]. Nigella sativa seed has a long history of unsurpassed medicinal value with versatility to treat a wide range of ailments, including headaches, asthma, colds, paralysis, pain, gastrointestinal problems, eczema, obesity and diabetes [10]. Only in this century have we begun to explore the potential of Nigella sativa seed, which continues to be useful in cooking, baking, pastries, cheeses, wine and as an ingredient in naan bread. Medicinally, it has been reported to treat amongst many things infections [11], hypertension [12], brain injury [13], opioid dependence [14] and cancer [15].

Thymoquinone (2-isopropyl-5-methyl-1, 4-benzoquinone, TQ) is believed to be the main active constituent of black cumin seed oil (BCS oil) responsible for suppressing the proliferation of tumor cells including colon, breast, bone, ovarian, prostate and pancreatic carcinoma $[16,17]$.

The main objective of the present study is to evaluate the efficacy of black cumin seed oil and TQ in suppressing the several underlying breast cancer related genes and respective changes in human mammary carcinoma tumor volume and tumor markers. So, the aim of the work was achieved using analysis of gene expression, specific biochemical markers as well as histopathological analysis using animal models of breast cancer compared to normal healthy animals. With knowledge and education, dietary modifications implemented into customary food preparation may provide a means to implement chemopreventive regimens for women in Arabian countries.

\section{Material and methods}

\section{Chemicals}

Chemicals for histopathological examination and biochemical analysis were purchased from SigmaAldrich ${ }^{\circledR}$ Chemie, GmbH, Riedstr. 2, D-89555 Steinheim, Germany. Reagents for gene expression analysis including kits, chemicals, and primers were purchased from Invitrogen and Sigma-Aldrich (Germany). All reagents and chemicals were of the highest purity available.

\section{Experimental animals}

Ninety adult female albino rats purchased from the Animal House Colony, Giza, Egypt, were maintained on standard laboratory diet (protein, 16.04\%; fat, 3.63\%; fiber, $4.1 \%$; and metabolic energy, $0.012 \mathrm{MJ}$ ) and water ad libitum at the Animal House Laboratory, National Research Center, Dokki, Giza, Egypt. After an acclimation period of 1 week and at 50 days of age, animals were divided into 9 groups (10 rats/group) and housed individually in filter-top polycarbonate cages kept in a temperature-controlled $\left(23 \pm 1^{\circ} \mathrm{C}\right)$ and artificially illuminated (12 h dark/light cycle) room free from any source of chemical contamination. All animals received humane care in compliance with the guidelines of the Animal Care and Use Committee of the National Research Center, Egypt.

\section{Experimental design}

Female albino rats $(n=90)$ at 50 days of age purchased from the Animal House Colony, Giza, Egypt were maintained on standard laboratory diet and water ad libitum at the Animal House Laboratory, National Research Center, Dokki, Giza, Egypt. The animals were allocated to two groups as follows: first group: untreated animals (control); second group: animals treated with a single dose of 7,12-dimethylbenz[a]anthracene (DMBA) $(65 \mathrm{mg} / \mathrm{kg}$ b.w.) via an intragastric tube to induce breast cancer. Animals in group two were divided into several subgroups as follows: subgroup 1: DMBA-treated animals left for 4 months without additional treatments; subgroups 2 to 4: DMBA-treated animals supplemented orally with $1,5,10 \mathrm{mg} / \mathrm{kg}$ of thymoquinone (TQ) via an intragastric tube three times per week for 4 months, respectively; subgroups 5 to 7: DMBA-treated animals supplement- 
ed orally with $1,5,10 \mathrm{mg} / \mathrm{kg}$ of black cumin seed oil (BCS oil) via an intragastric tube three times per week for 4 months, respectively; and subgroup 8: DMBA-treated animals supplemented with a breast cancer chemotherapy drug such as 5 -fluorouracil $(100 \mathrm{mg} / \mathrm{kg})$ three times per week for 4 months.

At the end of the experimental period, blood samples were collected from the retro-orbital venous plexus of all animals after fasting for $12 \mathrm{~h}$ for the biochemical analysis. The animals were sacrificed after 120 days of carcinogenic induction (DMBA treatment), and then the mammary gland tissues were extracted from all treatment groups. A part of the mammary gland tissues was kept in formalin solution (10\%) until the completion of the slaughter and beginning of analysis of histological examination for all treated groups. The other parts of the mammary glands were kept at $-20^{\circ} \mathrm{C}$ for biochemical analysis and at $-80^{\circ} \mathrm{C}$ for molecular analysis.

\section{Plant extracts}

\section{Supercritical fluid extraction of thymoquinone} rich fraction

According to Norsharina et al. [18], the thymoquinone rich fraction was extracted from $N$. sativa seeds using the supercritical fluid extraction (SFE) system with minor modifications. Briefly, N. sativa seeds were cleaned and dried in an oven at $40^{\circ} \mathrm{C}$ until a constant weight was obtained. One hundred grams of the seeds were ground into a powder for 1 min using an electrical grinder just before the SFE extraction was initiated. Then $100 \mathrm{~g}$ of $\mathrm{N}$. sativa powder were placed in the 1 I SFE extraction vessel. Extraction was performed using $\mathrm{CO}_{2}$ supplied to an extraction unit. The unit was equipped with an extractor vessel and three cyclone separators. The extraction vessel was tightly sealed and the desired extraction temperature at $40^{\circ} \mathrm{C}$ and pressure at 600 bar were set. The SFE flow rate was maintained at $30.00 \mathrm{ml} / \mathrm{min}$ and regulated by an automated back pressure regulator. The entire extraction process required $3 \mathrm{~h}$ and the resulting oil samples were collected from the system collection vessel, weighed and kept at $-20^{\circ} \mathrm{C}$ in amber bottles for further analysis. Thymoquinone was identified and quantified by HPLC on a reversed-phase Reprosil Gold 120 C18 analytical column $(250 \mathrm{~mm} \times 4.6 \mathrm{~mm}, 5 \mu \mathrm{m}$ particle size) using an isocratic mobile phase of water: methanol: 2-propanol (50: $45: 5 \% \mathrm{v} / \mathrm{v})$ at a flow rate of $1 \mathrm{ml} / \mathrm{min}$. Ultraviolet monitoring was carried out at $254 \mathrm{~nm}$. The concentration of thymoquinone in the total crude oil was about $0.103 \%(w / v)$.

\section{Extraction and essential oil analysis of fixed oil}

The oil from the black cumin seed was extracted through the solvent extraction technique as described in AOCS [19]; hexane was used as a sol- vent. The extracted oil was stored in a dark place at room temperature. Essential oil was extracted following the method of Kanter et al. [20].

\section{Histopathological examination}

Tissue specimens from the mammary gland of female rats of several experimental groups were fixed in neutral buffered formalin 10\% and processed by a conventional method, embedded in paraffin, sectioned at 4-5 $\mu \mathrm{m}$ and stained by hematoxylin and eosin [21].

\section{Biochemical analyses}

Blood serum was obtained from whole blood by leaving to coagulate for $20 \mathrm{~min}$ at $4^{\circ} \mathrm{C}$ then centrifuged at $2000 \mathrm{~g}$ for $15 \mathrm{~min}$ and then the upper phase from the blood after centrifugation was freshly subjected to biochemical analysis for some tumor markers as follows:

\section{Determination of malondialdehyde}

Concentration of malondialdehyde (MDA) was measured by the thiobarbituric acid test according to the method described by Ohkawa et al. [22] using a Biodiagnostic kit, Egypt. Results were expressed as nmol thiobarbituric acid reactive substances $/ \mathrm{ml}$.

\section{Determination of lactate dehydrogenase}

Lactate dehydrogenase (LDH) activity (U/I) was estimated according to the method of Buhl and Jackson [23] using a Stanbio Laboratory kit, USA.

\section{Determination of alkaline phosphatase}

Determination of alkaline phosphatase (ALP) (IU/L) was carried out referring to the DGKC indications, Germany [24].

\section{Determination of aspartate aminotransferase and alanine aminotransferase}

Aspartate aminotransferase (AST) and alanine aminotransferase (ALT) activities were measured using kits of QCA, Spain, according to the method of Reitman and Frankel [25]. The AST and ALT activities were expressed as $\mathrm{U} / \mathrm{l}$.

\section{RNA extraction}

TRIzol ${ }^{\circledR}$ Reagent (cat\#15596-026, Invitrogen, Germany) was used to extract total RNA from mammary gland tissues of female rats according to the manufacturer's instructions with minor modifications.

Briefly, tissue samples (50 mg) were homogenized in $1 \mathrm{ml}$ of TRIzol ${ }^{\circledR}$ Reagent. Afterwards, the 
homogenized sample was incubated for $15 \mathrm{~min}$ at room temperature. A volume of $0.2 \mathrm{ml}$ of chloroform per $1 \mathrm{ml}$ of TRIzol ${ }^{\circledR}$ Reagent was added. Then, the samples were vortexed vigorously for $15 \mathrm{~s}$ and incubated at room temperature for $3 \mathrm{~min}$. The samples were centrifuged for no more than $12000 \mathrm{~g}$ for $15 \mathrm{~min}$ at $4^{\circ} \mathrm{C}$. Following centrifugation, the mixture was separated into a lower red, phenol-chloroform phase, an interphase, and a colorless upper aqueous phase. RNA remained exclusively in the aqueous phase. Therefore, the upper aqueous phase was carefully transferred without disturbing the interphase into a fresh tube. The RNA was precipitated from the aqueous phase by mixing with isopropyl alcohol. A volume of $0.5 \mathrm{ml}$ of isopropyl alcohol was added per $1 \mathrm{ml}$ of TRIzol ${ }^{\circledR}$ Reagent used for the initial homogenization. Afterwards, the samples were incubated at $15^{\circ} \mathrm{C}$ to $30^{\circ} \mathrm{C}$ for $10 \mathrm{~min}$ and centrifuged at not more than $12,000 \times \mathrm{g}$ for $10 \mathrm{~min}$ at $4^{\circ} \mathrm{C}$. The RNA, which was often invisible before centrifugation, was precipitated, forming a gel-like pellet on the side and bottom of the tube. The supernatant was removed completely. The RNA pellet was washed once with $1 \mathrm{ml}$ of $75 \%$ ethanol. The samples were mixed by vortexing and centrifuged at no more than $7500 \mathrm{~g}$ for $5 \mathrm{~min}$ at $4^{\circ} \mathrm{C}$. The supernatant was removed and the RNA pellet was air-dried for 10 min. RNA was dissolved in diethylpyrocarbonate (DEPC)-treated water by passing the solution a few times through a pipette tip.

Total RNA was treated with 1 unit of RQ1 RNasefree DNase (Invitrogen, Germany) to digest DNA residues, re-suspended in DEPC-treated water and quantified photospectrometrically at $260 \mathrm{~nm}$. Purity of total RNA was assessed by the $260 / 280 \mathrm{~nm}$ ratio, which was between 1.8 and 2.1. Additionally, integrity was assured with ethidium bromide stain analysis of $28 \mathrm{~S}$ and $18 \mathrm{~S}$ bands by formaldehydecontaining agarose gel electrophoresis (data not shown). Aliquots were used immediately for reverse transcription (RT), otherwise they were stored at $-80^{\circ} \mathrm{C}$.

\section{Reverse transcription (RT) reaction}

The complete poly $(A)^{+}$RNA isolated from mammary gland tissues of female rats was reverse transcribed into cDNA in a total volume of $20 \mu$ using the RevertAid ${ }^{T M}$ First Strand cDNA Synthesis Kit (MBI Fermentas, Germany). An amount of total RNA (5 $\mu \mathrm{g}$ ) was used with a reaction mixture, termed the master $\operatorname{mix}(M M)$. The $M M$ consisted of $50 \mathrm{mM} \mathrm{MgCl}_{2}, 5 \times$ reverse transcription (RT) buffer (50 mM KCl; $10 \mathrm{mM}$ Tris- $\mathrm{HCl}$; $\mathrm{pH}=8.3$ ), $10 \mathrm{mM}$ of each dNTP, $50 \mu \mathrm{M}$ oligo-dT primer, $20 \mathrm{U}$ ribonuclease inhibitor (50 kDa recombinant enzyme to inhibit RNase activity) and $50 \mathrm{U}$ M-MuLV reverse transcriptase. The RT reaction was carried out at $25^{\circ} \mathrm{C}$ for $10 \mathrm{~min}$, followed by $1 \mathrm{~h}$ at $42^{\circ} \mathrm{C}$, and the reaction was stopped by heating for 5 min at $99^{\circ} \mathrm{C}$. Afterwards the reaction tubes containing RT preparations were flash-cooled in an ice chamber until used for DNA amplification through semiquantitative real-time polymerase chain reaction (sqRT-PCR).

\section{Semi-quantitative real-time polymerase chain reaction}

An iQ5-BIO-RAD Cycler (Cepheid, USA) was used to determine rat mammary gland cDNA copy number. PCR reactions were set up in $25 \mu \mathrm{l}$ reaction mixtures containing $12.5 \mu \mathrm{l}$ of $1 \times \mathrm{SYBR}^{\circledR}$ Premix Ex Taq $^{\text {TM }}$ (TaKaRa, Biotech. Co. Ltd.), $0.5 \mu$ of $0.2 \mu \mathrm{M}$ sense primer, $0.5 \mu \mathrm{l}$ of $0.2 \mu \mathrm{M}$ antisense primer, $6.5 \mu \mathrm{l}$ of distilled water, and $5 \mu \mathrm{l}$ of cDNA template. The reaction program was allocated to 3 steps. The first step was at $95.0^{\circ} \mathrm{C}$ for $3 \mathrm{~min}$. The second step consisted of 40 cycles in which each cycle was divided into 3 steps: (a) at $95.0^{\circ} \mathrm{C}$ for $15 \mathrm{~s}$; (b) at $55.0^{\circ} \mathrm{C}$ for $30 \mathrm{~s}$; and (c) at $72.0^{\circ} \mathrm{C}$ for $30 \mathrm{~s}$. The third step consisted of $71 \mathrm{cycles}$ which started at $60.0^{\circ} \mathrm{C}$ and then increased about $0.5^{\circ} \mathrm{C}$ every $10 \mathrm{~s}$ up to $95.0^{\circ} \mathrm{C}$. At the end of each sqRT-PCR a melting curve analysis was performed at $95.0^{\circ} \mathrm{C}$ to check the quality of the used primers [26]. Each experiment included a distilled water control.

Several genes are related to breast cancer such as breast cancer genes 1 and 2 (Brca1 and Brca2), Id-1 (inhibitor of DNA binding) protein gene and P53 mutation. The semi-quantitative values of RT-PCR (sqRT-PCR) of Brcal (Brca1-F: 5'-CAG ATT GAG TCT GGA AGT GCC A-3', Brca1-R: 5'-TGT TTT GAG GTT GTG TCT GCC TAT-3', GenBank accession no. AF036760), Brca2 (Brca2-F: 5'-TTG AGG ACC CCA AGA CCT GT-3', Brca2-R: 5'-CCG GAG AGA CAA AGG TGC A-3', GenBank accession no. U89653), Id-1 (Id1-F: 5'-AGG TGG TGC GCT GTC TGT CT-3', Id-1-R: 5'TAA TTC CTC TTG CCC CCT GG-3') [27], and p53 (p53-F: 5'-GCG GTA CCC CAG GTC GGC GAG AAT CC3', p53-R: 5'-GGG CTC GAG TCT AGA CTT TTG AGA $A G(-3$ ') [27] genes were normalized on the bases of $\beta$-actin $(\beta$-actin-F: 5'-GCG GGA AAT CGT GCG TGA CAT T-3', $\beta$-actin-R: 5'-GAT GGA GTT GAA GGT AGT TTC GTG-3') [28] expression.

At the end of each sqRT-PCR a melting curve analysis was performed at $95.0^{\circ} \mathrm{C}$ to check the quality of the used primers.

\section{Calculation of gene expression}

First the amplification efficiency (Ef) was calculated from the slope of the standard curve using the following formulae [29]: $E f=10^{-1 / \text { slope }}$, efficiency $(\%)=(E f-1) \times 100$.

The relative quantification of the target to the reference was determined by using the $\Delta \mathrm{C}_{\mathrm{T}}$ method if $E f$ for the target (Brca1, Brca2, Id-1 and P53) 


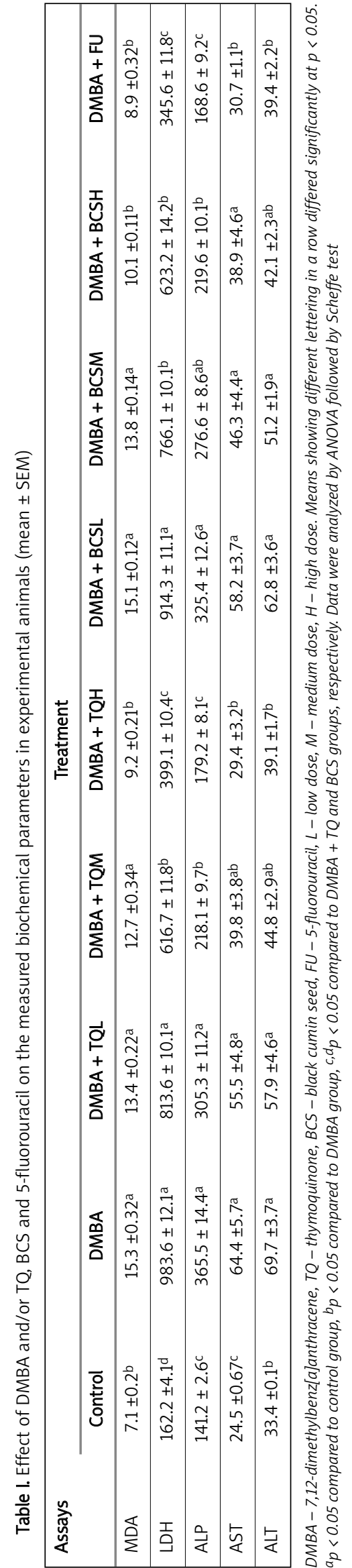

and the reference primers ( $\beta$-actin) were the same [29]:

$$
\text { Ratio }_{(\text {reference/ target gene) }}=\mathrm{EfC}_{\mathrm{T}} \text { (reference) }-\mathrm{C}_{\mathrm{T}} \text { (target) } \text {. }
$$

\section{Statistical analysis}

All results were expressed as mean \pm SE of the mean. Data were analyzed by one-way analysis of variance (ANOVA) using the Statistical Package for the Social Sciences (SPSS) program, version 11, followed by Scheffe test to compare significance between groups. Differences were considered significant when $p>0.05$.

\section{Results \\ Biochemical analysis}

The results presented in Table I showed that the DMBA-treated rats exhibited significantly higher values of MDA and LDH levels, and ALP and AST activities compared to the control rats $(t=4.35$, $\mathrm{d} f=14, p<0.001)$. However, treatment of female rats with TQ and BCS oil decreased the MDA and $\mathrm{LDH}$ levels, and ALP and AST activities induced by DMBA. The values of MDA and LDH levels, and ALP and AST activities were significantly decreased with the highest dose of TQ and BCS oil compared with the DMBA-treated group $(t=3.76, \mathrm{~d} f=11$, $p<0.005$, Table I). However, the low and medium doses of TQ and BCS oil decreased the MDA and LDH levels, and ALP and AST activities without significant differences ( $t=0.757, \mathrm{~d} f=10, \mathrm{NS}$ ) except the ALP activity induced with the medium dose of TQ and LDH induced by the medium dose of BCS oil, which decreased significantly compared to the DMBA group ( $t=3.497, \mathrm{~d} f=10, p<0.01$, Table I). On the other hand, treatment with 5-fluorouracil in female DMBA-treated rats significantly decreased the values of MDA and LDH levels, and ALP and AST activities compared with the DMBA group $(t=3.76$, $\mathrm{d} f=11, p<0.005$, Table I).

\section{Histopathological analysis}

Comparison of control and DMBA treated mammary gland after 120 days is shown in Figure 1. Histopathological analyses were performed on mammary tissue from all control and DMBA-treated animals. The results show that the mammary tissue of control rats did not have any abnormal tissues.

The mammary gland of control rats showed normal lobular architecture with branched ducts and normal distribution of fat tissue. The control mammary tissue at 120 days was unchanged relative to earlier time points. However, treatment with DMBA alone induced tumors in the mammary tissues of rats at 120 days of treatment. The histomorphological analysis revealed ductal carcinomas in situ 

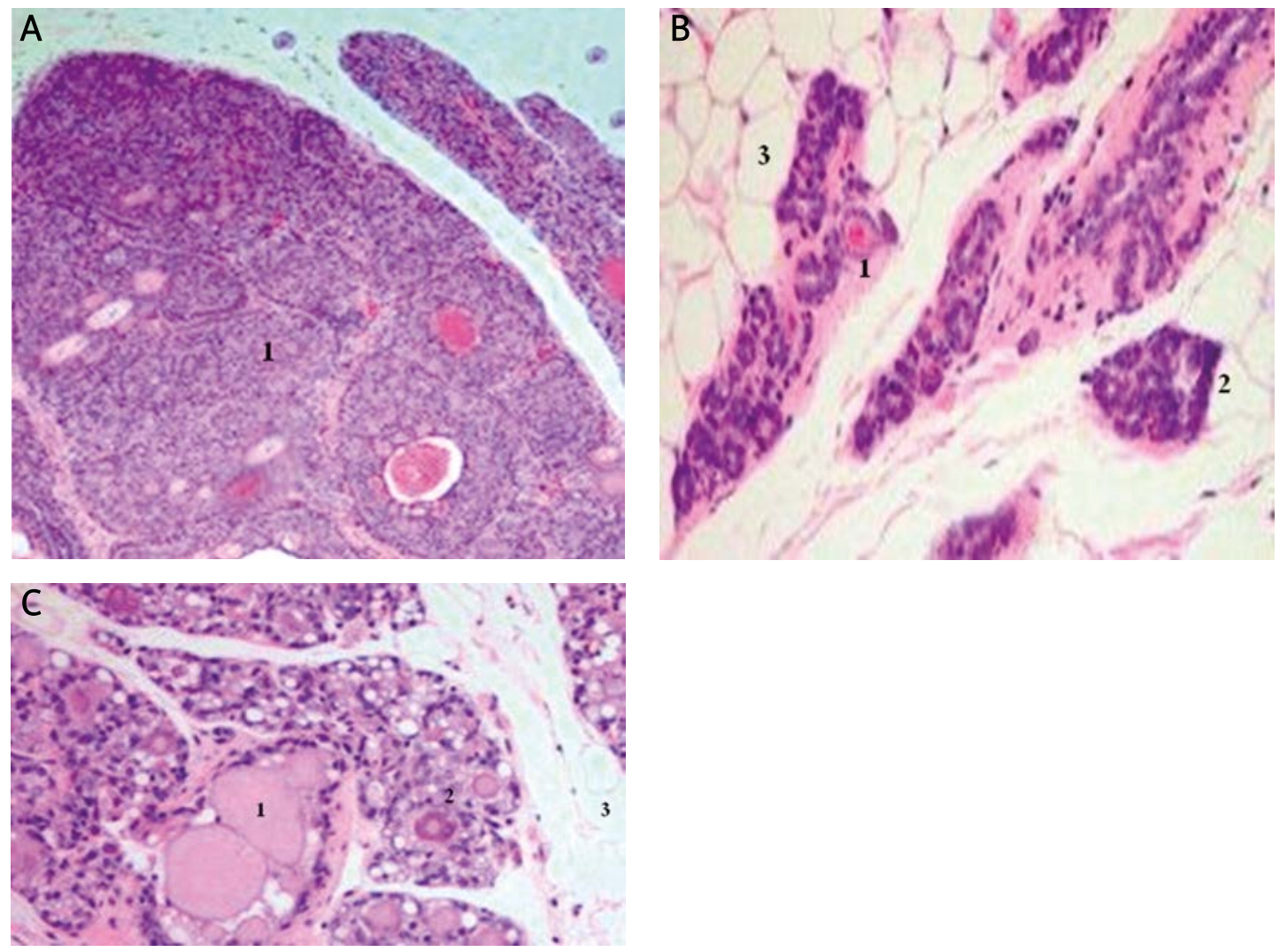

Figure 1. Photomicrographs of mammary tissue of female rats. Comparison of DMBA-treated mammary gland after 120 days and control or protected mammary gland with TQ or BCS. Histopathological analyses were performed on mammary tissue from all control and DMBA-treated animals. This figure shows mammary tissue representative of the morphology generally observed in DMBA-treated animals and control rats. A - Histomorphological analysis revealed carcinomas in situ (1). The carcinomas showed mixed morphology, with solid patterns with or without comedo-necrosis predominating, but cribriform and cystic-papillary patterns were also present. B - The mammary gland of control rats shows normal lobular architecture (1) with branched ducts (2) and normal distribution of fat tissue (3). The control mammary tissue at 120 days is unchanged relative to earlier time points. Similar observation was made with TQ- or BCS oil-treated rats as seen in C - The TQ or BCS oil stimulated mammary gland shows increased proliferation with dilated ducts containing inspissated secretions (1) and increased proliferation and expansion of terminal lobular units (2) accompanied by compression of and expansion into the surrounding fat tissue (3)

(DCIS) (Figure $1 \mathrm{~A})$. The carcinomas exhibited a mixed morphology, with solid patterns combined with or without comedo-necrosis predominating. Moreover, the figure also shows cribriform and cystic-papillary patterns. When cribriform and cysticpapillary patterns were present, the invasion was limited to foci of micro-invasion. The micro-invasive foci were observed and described by breakdown of the basal membrane of the in situ lesion by proliferation of atypical small glands. These glands invaded the surrounding stroma surrounded by a prominent desmoplastic reaction. In contrast, similar observation to the control tissues was made with TQ- or BCS oil-treatment rats. The control as well as the TQ- or BCS oil stimulated mammary gland showed increased proliferation with dilated ducts containing inspissated secretions and increased proliferation and expansion of terminal lobular units accompanied by compression of and expansion into the surrounding fat tissues.

\section{Expression analysis of several genes related to breast cancer}

Results of the expression of breast cancer genes 1 and 2 (Brca1 and Brca2), Id-1 (inhibitor of DNA binding) protein gene and p53 mutation in rat mammary gland tissues treated with DMBA are shown in Figures 2-5. The results revealed that expression levels of Brca1 and Brca2 genes were higher than those in $1 d-1$ and $p 53$ genes.

The results revealed that Brca1 and Brca2 genes in mammary gland tissues collected from DMBAtreated rats were significantly over-expressed compared with control and all other groups $(t=3.759$, $\mathrm{d} f=12, p<0.001$, Figures 2 and 3 ). However, treatment of DMBA rats with TQ at low, medium and high doses significantly decreased the expression of Brca1 and Brca2 genes compared with DMBA rats $(t=2.959, \mathrm{~d} f=10, p<0.05)$. In addition, the highest dose of TQ was more effective than low and 


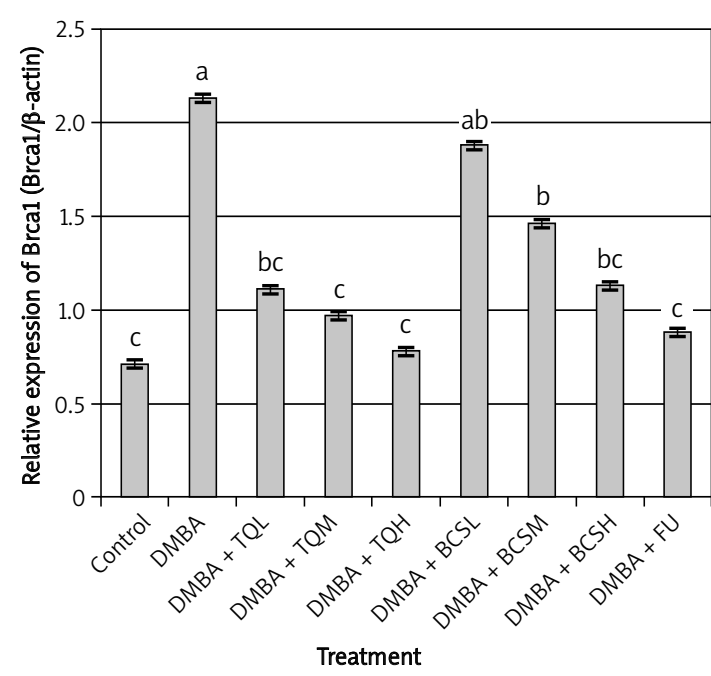

Figure 2. Effect of TQ and BCS on the expression of Brcal gene in mammary gland tissues of DMBAtreated rats using semi-quantitative real-time PCR analysis. Means showing different lettering $(a, b, c)$ between columns differed significantly at $p<0.05$. a $p<0.05$ compared to control group, $b_{p}<0.05$ compared to DMBA group, $c p<0.05$ compared to DMBA $+\mathrm{TQ}$ and BCS groups, respectively. Data were analyzed by ANOVA followed by Scheffe test

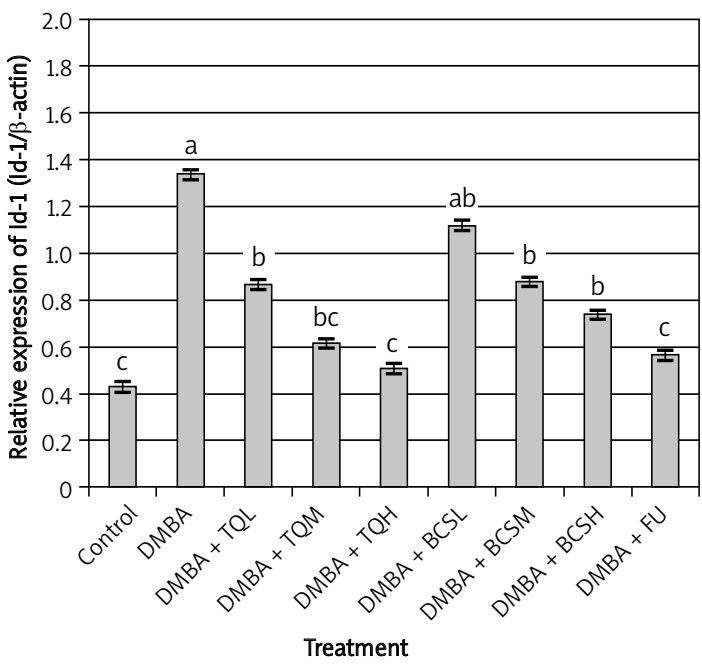

Figure 4. Effect of TQ and BCS on the expression of Id-1 gene in mammary gland tissues of DMBA-treated rats using semi-quantitative real-time PCR analysis. Means showing different lettering $(a, b, c)$ between columns differed significantly at $p<0.05$. a $p<0.05$ compared to control group, $b_{p}<0.05$ compared to DMBA group, ${ }^{c} p<0.05$ compared to DMBA $+\mathrm{TQ}$ and BCS groups, respectively. Data were analyzed by ANOVA followed by Scheffe test

medium doses of TQ in decreasing the expression of Brca1 and Brca2 genes. The same trend was observed regarding the expression of Id- 1 and p53 genes in DMBA rats treated with TQ $(t=3.945$, $\mathrm{d} f=13, p<0.0001$, Figures 4 and 5$)$ in which all doses of TQ significantly decreased the over-expression

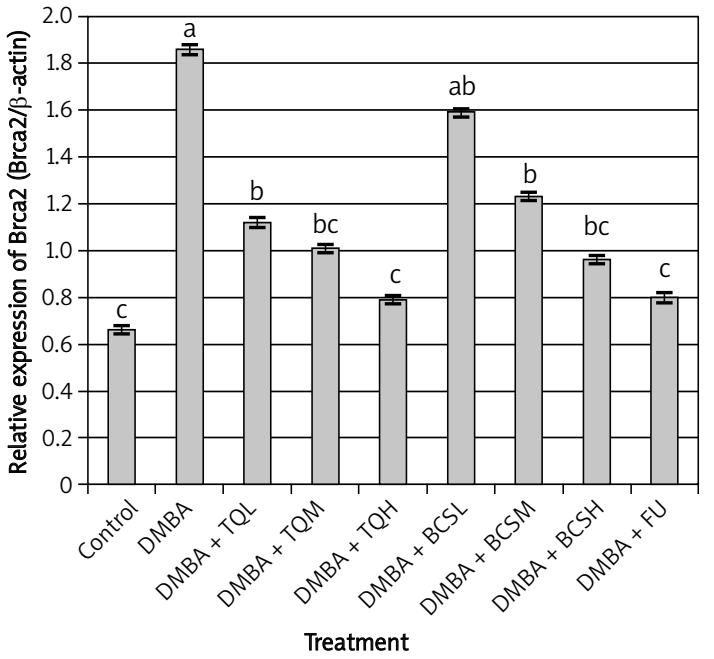

Figure 3. Effect of TQ and BCS on the expression of Brca2 gene in mammary gland tissues of DMBAtreated rats using semi-quantitative real-time PCR analysis. Means showing different lettering $(a, b, c)$ between columns differed significantly at $p<0.05$. a $p<0.05$ compared to control group, b $p<0.05$ compared to DMBA group, ${ }^{c} p<0.05$ compared to DMBA $+\mathrm{TQ}$ and BCS groups, respectively. Data were analyzed by ANOVA followed by Scheffe test

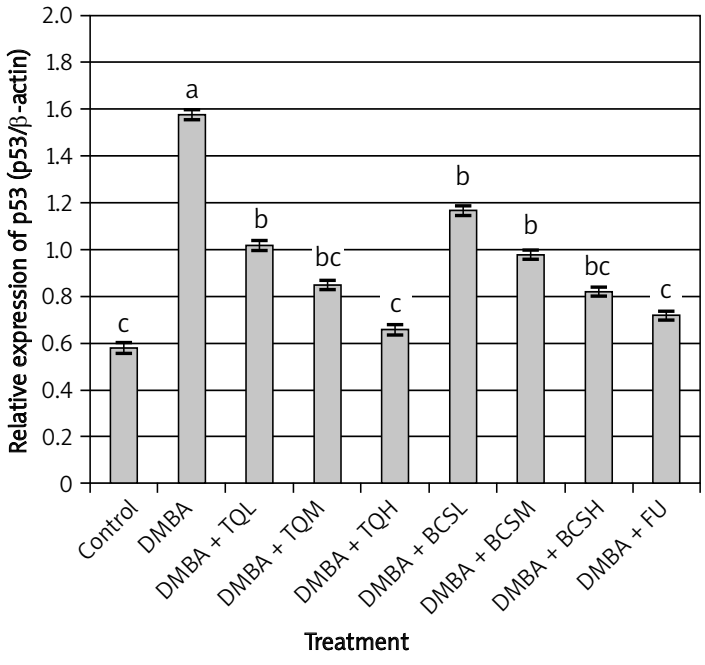

Figure 5. Effect of TQ and BCS on the expression of p53 mutation in mammary gland tissues of DMBAtreated rats using semi-quantitative real-time PCR analysis. Means showing different lettering $(a, b, c)$ between columns differed significantly at $p<0.05$. a $p<0.05$ compared to control group, $b_{p}<0.05$ compared to DMBA group, ${ }^{c} p<0.05$ compared to DMBA $+\mathrm{TQ}$ and BCS groups, respectively. Data were analyzed by ANOVA followed by Scheffe test

of Id- 1 and p53 genes induced by DMBA treatment. In addition, the lowest expression levels of the Id-1 and $\mathrm{p} 53$ genes were observed in DMBA rats treated with the highest dose of TQ (Figures 4 and 5).

On the other hand, treatment of DMBA rats with BCS was less effective than TQ in decreasing the 
expression levels of Brca1, Brca2, Id-1 and p53 genes. The expression levels of Brca1, Brca2 and Id-1 genes in DMBA rats were relatively similar to those in DMBA rats treated with a low dose of BCS $(t=2.124, \mathrm{~d} f=10, p<0.06$, Figures $2-4)$, while the low dose of BCS significantly decreased the expression level of the $\mathrm{p} 53$ gene in DMBA rats compared with that in DMBA rats without BCS $(t=2.989$, $\mathrm{d} f=10, p<0.05$, Figure 5).

However, the ability of BCS to decrease the expression levels of Brca1, Brca2, Id-1 and p53 genes was more effective at the medium and high doses. These doses of BCS significantly decreased the expression levels of Brca1, Brca2, Id- 1 and $p 53$ genes compared with those in DMBA rats $(t=3.984$, $\mathrm{d} f=12, p<0.005$, Figures $2-5$ ).

The effect of 5-fluorouracil on the expression levels of Brca1, Brca2, Id-1 and p53 genes was relatively similar to the effect of the highest dose of TQ $(t=4.124, \mathrm{~d} f=13, p<0.0001$, Figures $2-5)$.

\section{Discussion}

Nigella sativa is an annual plant with grayishblue flowers. The pods of the plant contain black seeds that possess immense medicinal value. The seeds contain fixed oils, essential oils and chemicals, such as thymoquinone, which help treat a variety of conditions including gastrointestinal disorders, hypertension, diabetes, bronchitis, fever and dizziness [30].

A variety of herbal and plant extracts or preparations are available today for treating any number of diseases affecting the human body. Like most herbs, the composition of black cumin varies with the geographic distribution, time of harvest and agronomic practices. Scientific investigations have depicted its composition, i.e. moisture, oil, proteins, ash and total carbohydrate contents in the range of $3.8-7.0 \%, 22.0-40.35 \%, 20.85-31.2 \%, 3.7-4.7 \%$ and 24.9-40.0\%, respectively [31, 32]. Its health-enhancing potential has been attributed to the active ingredients that are mainly present in its fixed or essential oils [33]. Therefore, the main objective of the current study was to evaluate the efficacy of black cumin seed oil and TQ extract on suppressing the several underlying breast cancer related genes and respective changes of human mammary carcinoma tumor volume and tumor markers. To our knowledge, there are no data discussing the protective role of TQ and BCS oil in inhibition of the growth of breast cancer induced by DMBA in female rats.

The histopathological examination of the current study revealed that DMBA-treated rats supplemented with TQ or BCS oil showed stimulation in the mammary gland and suppression in the progress of the mammary tumor cell proliferation. In agreement with our findings Attia-Zouair et al. [34] showed limitation in the neoplastic changes during the sequential steps of carcinogenesis in DMBA-treated male Syrian hamsters supplemented with Nigella sativa. Also, Aruna and Sivaramakrishnan [35] described the use of spices, leafy vegetables and condiments having diverse medicinal properties. Products of 20 spices or leafy vegetables including Cuminum cyminum Linn. (black cumin) were screened for anti-carcinogenic activity. Black seed preparations have also demonstrated significant in vitro and in vivo antineoplastic activity [36].

Tumor progression due to DMBA treatment is almost always accompanied by an increase in the oxidation process. In contrast, the anti-carcinogenic effectiveness of Nigella sativa is attributed to several reasons, including enhancement of anti-oxidation activity. Aruna and Sivaramakrishnan [35] found that anti-carcinogenic efficiency of Nigella sativa was found with the increase of glutathioneS-transferase activity. In line with these findings, the results of the current study found that TQ and BCS oil were able to decrease the progress of mammary tumors in female rats induced by DMBA as well as decrease the values of MDA and LDH levels, ALP and AST.

Expression analysis of tumor-related genes is important to understand the biological mechanism of cancer development. BRCA1 and BRCA2 genes are initially proposed to be responsible for the majority of inherited breast cancer [4]. In addition, the Id gene regulates the control of cellular processes related to tumor progression [6]. Fong et al. [7] found that reducing Id-1 using antisense technology led to significant reductions in breast cancer cell proliferation and invasiveness in vitro and metastasis in vivo in mice [7]. Furthermore, although the tumor suppressor gene p53 has been reported to be able to regulate the expression of a number of downstream proteins, mutation in p53 is known to be responsible for cancer development. Our current study revealed that TQ and then BCS were able to decrease the expression of the Brca1, Brca2, Id-1 and P53 mutations in mammary tissues of female rats induced by DMBA treatment.

Although TQ and BCS have been shown to suppress the growth of tumor cells, the inhibitory effect of this compound in breast cancer is not well documented. Salomi et al. [37] studied $N$. sativa seeds containing certain fatty acids for antitumor activities against Ehrlich ascites carcinoma (EAC), Dalton's lymphoma ascites (DLA) and sarcoma-180 (S-180) cells. They found that the active principle of the fatty acids was cytotoxic for EAC cells, KB cells and lymphocytes. Furthermore, Salomi et al. [38] reported the effect of the active principle isolated from N. sati$v a$ in inhibiting chemically induced skin carcinogenesis. They found that intraperitoneal administration of $N$. sativa extract prevented incidents of soft tissue sarcomas and reduced tumor diameters 
in treated groups. In addition to the previous findings, thymoquinone found in black seed oil can lead to programmed cell death of human colorectal cancer cells in the laboratory, according to the study reported by Gali-Muhtasib et al. [30]. Additionally, Ivankovic et al. [39] indicated that thymoquinone and thymohydroquinone exhibit significant antitumor activity on cancer cells in the laboratory. Thymoquinone is a powerful antioxidant that also may protect the tissues from radiation injury. It also inhibits DNA synthesis and causes programmed cell death of stomach cancer cells in animal models.

The remediation mechanism of TQ and BCS against breast cancer was attributed to their antioxidant activity [40]. The prominent antioxidant activity of $N$. sativa was extensively documented in different experimental situations, including hepatocarcinogenesis [41-43]. It has been shown that both the fixed oil of $N$. sativa and thymoquinone inhibit non-enzymatic lipid peroxidation in liposomes [44]. Using thin-layer chromatography (TLC), it has also been shown that compounds isolated from $N$. sativa (including thymoquinone, carvacrol, t-anethole and 4-terpineol) have appreciable free radical scavenging properties [45]. These compounds were found in a series of other in vitro tests to have antioxidant activity, but no pro-oxidant properties. The antioxidant action of $N$. sativa may explain its claimed usefulness in folk medicine. This antioxidant property would explain its action against $\mathrm{CCl}_{4}$ hepatotoxicity [46], liver fibrosis and cirrhosis [47], and hepatic damage induced by Schistosoma mansoni infection [48].

In conclusion, the results of the present study give clear evidence that Nigella sativa extract and thymoquinone induce no harmful effects on female rat breast tissues. Moreover, they exert a protective effect against breast carcinogens. The antioxidant property is mediated by their actions and investigating other underlying mechanisms merits further studies.

\section{Acknowledgments}

This research was supported by a grant from King Abdulaziz University (Grant: 1432/247/446). The authors thank everyone who assisted in this study. We are grateful to the deanship of scientific research for financial support to conduct this research.

\section{Conflict of interest}

The authors declare no conflict of interest.

\footnotetext{
References

1. Eckhardt S. Anti-cancer agents. Curr Med Chem 2002; 2: 419-9.

2. Casey G. The BRCA1 and BRCA2 breast cancer genes. Curr Opin Oncol 1997; 9: 88-93.
}

3. Omar S, Khaled H, Gaafar R, Zekry AR, Eissa S, El-Khatib O. Breast cancer in Egypt: a review of disease presentation and detection strategies. East Mediterr Health J 2003; 9: 448-63.

4. Hedenfalk IA, Ringnér M, Trent JM, Borg A. Gene expression in inherited breast cancer. Adv Cancer Res 2002; 84: 1-34.

5. Benezra R, Davis RL, Lockshon D, Turner DL, Weintraub H. The protein Id: a negative regulator of helix-loop-helix DNA binding proteins. Cell 1990; 61: 49-59.

6. Perk J, lavarone A, Benezra R. Id family of helix-loop-helix proteins in cancer. Nat Rev Cancer 2005; 5: 603-14.

7. Fong S, Itahana Y, Sumida T, et al. Id-1 as a molecular target in therapy for breast cancer cell invasion and metastasis. Proc Natl Acad Sci U S A 2003; 100: 13543-8.

8. Minn AJ, Gupta GP, Siegel PM, et al. Genes that mediate breast cancer metastasis to lung. Nature 2005; 436: 518-24.

9. Padhye S, Banerjee S, Ahmad A, Mohammad R, Sarkar FH. From here to eternity - the secret of Pharaohs: therapeutic potential of black cumin seeds and beyond. Cancer Ther 2008; 6: 495-510.

10. Tariq M. Nigella sativa seeds: folklore treatment in modern day medicine. Saudi J Gastroenterol 2008; 14: 105-6.

11. Hannan A, Saleem S, Chaudhary S, Barkaat M, Arshad MU. Anti bacterial activity of Nigella sativa against clinical isolates of methicillin resistant Staphylococcus aureus. J Ayub Med Coll Abbottabad 2008; 20: 72-4.

12. Dehkordi FR, Kamkhah AF. Antihypertensive effect of Nigella sativa seed extract in patients with mild hypertension. Fundam Clin Pharmacol 2008; 22: 447-52.

13. Kanter M. Protective effects of Nigella sativa on the neuronal injury in frontal cortex and brain stem after chronic toluene exposure. Neurochem Res 2008; 33: 2241-9.

14. Sangi S, Ahmed SP, Channa MA, Ashfaq M, Mastoi SM. A new and novel treatment of opioid dependence: Nigella sativa 500 mg. J Ayub Med Coll Abbottabad 2008; 20: 118-24.

15. Ait Mbarek L, Ait Mouse H, Elabbadi N, et al Anti-tumor properties of blackseed (Nigella sativa L.) extracts. Braz J Med Biol Res 2007; 40: 839-47.

16. Aggarwal BB, Kunnumakkara AB, Harikumar KB, Tharakan ST, Sung B, Anand P. Potential of spice-derived phytochemicals for cancer prevention. Planta Med 2008; 74: 1560-9.

17. Kaseb AO, Chinnakannu K, Chen D, et al. Androgen receptor and E2F-1 targeted thymoquinone therapy for hormone-refractory prostate cancer. Cancer Res 2007; 67: 7782-8.

18. Norsharina I, Maznah I, Aied A, Ghanya A. Thymoquinone rich fraction from Nigella sativa and thymoquinone are cytotoxic towards colon and leukemic carcinoma cell lines. J Med Plants Res 2011; 5: 3359-66.

19. AOCS. Official Methods and Recommended Practices of AOCS, fifth ed. American Oil Chemical Society, Campaign, Illinions. 1998.

20. Kanter M, Meral I, Yener Z, Ozbek H, Demir H. Partial regeneration/ proliferation of the beta-cells in the islets of Langerhans by Nigella sativa L. in streptozotocininduced diabetic rats. Tohoku J Exp Med 2003; 201: 213-9.

21. Bancroft JD, Stevens A, Turner DR. Theory and practice of histological techniques. $4^{\text {th }}$ ed. New York, Churchill, Livingstone 1996.

22. Ohkawa H, Ohishi N, Yagi K. Assay for lipid peroxides in animal tissues by thiobarbituric acid reaction. Anal Biochem 1979; 95: 351-8. 
23. Buhl SN, Jackson KY. Optimal conditions and comparison of lactate dehydrogenase catalysis of the lactate-topyruvate and pyruvate-to-lactate reactions in human serum at 25, 30, and 37 degrees C. Clin Chem 1978; 24: 828-31.

24. DGKC: Deutsche Gesellschaft für klinische Chemie. Empfehlungen der deutschen Gesellschaft für Klinische Chemie. 1972. Recommendation of the German Society of Clinical Chemistry. Standardization of methods for measurement of enzymatic activities in biological fluids. Z Klin Chem Klin Biochem 1972; 281: 91.

25. Reitman S, Frankel S. A colorimetric method for the determination of serum glutamic oxaloaceytate aminotransferase. Am J Clin Pathol 1957; 28: 56-63.

26. Kumar V, Khalil WK, Weiler U, Becker K. Influences of incorporating detoxified Jatropha curcas kernel meal in common carp (Cyprinus carpio L.) diet on the expression of growth hormone- and insulin-like growth factor-1encoding genes. J Anim Physiol Anim Nutr 2013; 97: 97-108.

27. McAllister SD, Christian RT, Horowitz MP, Garcia A, Desprez PY. Cannabidiol as a novel inhibitor of Id-1 gene expression in aggressive breast cancer cells. Mol Cancer Ther 2007; 6: 2921-7.

28. Qin C, Nguyen T, Stewart J, Samudio I, Burghardt R, Safe S. Estrogen up-regulation of p53 gene expression in MCF-7 breast cancer cells is mediated by calmodulin kinase IV-dependent activation of a nuclear factor kappaB/CCAAT-binding transcription factor-1 complex. Mol Endocrinol 2002; 16: 1793-809.

29. Bio-Rad Laboratories Inc. Real-Time PCR Applications Guide. Bulletin 2006; 5279: 101

30. Gali-Muhtasib H, Diab-Assaf M, Boltze C, et al. Thymoquinone extracted from black seed triggers apoptotic cell death in human colorectal cancer cells via a p53dependent mechanism. Int J Oncol 2004; 25: 857-66.

31. Takruri HRH, Dameh MAF. Study of nutritional value of black cumin seeds (Nigella sativa L). J Sci Food Agric 1998; 76: 404-10.

32. Atta MB. Some characteristics of nigella (Nigella sativa L.) seed cultivated in Egypt and its lipid profile. Food Chem 2003; 83: 63-8.

33. Ramadan MF. Nutritional value, functional properties and nutraceuticals applications of black cumin (Nigella sativa L.): an overview. Int J Food Sci Technol 2007; 42: 1208-18.

34. Attia-Zouair MG, Nagatsuka H, Mostafa KA, Nagai N. Effect of vitamin $E$ and Nigella sativa on cell proliferation and differentiation during sequential oral carcinogenesis. Int J Oral Maxillofac Surg 1997; 26 (Suppl. 1): 269.

35. Aruna K, Sivaramakrishnan VM. Plant products as protective agents against cancer. Indian J Exp Biol 1990; 28: 1008-11.

36. Rooney S, Ryan MF. Effects of alphahederin and thymoquinone, constituents of Nigella sativa, on human cancer cell lines. Anticancer Res 2005; 25: 2199-204.

37. Salomi NJ, Nair SC, Jayawardhanan KK, Varghese CD, Panikkar KR. Antitumour principles from Nigella Sativa seeds. Cancer Lett 1992; 63: 41-6.

38. Salomi MJ, Nair SC, Panikkar KR. Inhibitory effects of Nigella Sativa and saffron (Crocus Sativus) on chemical carcinogenesis in mice. Nutr Cancer 1991; 16: 67-72.

39. Ivankovic S, Stojkovic R, Jukic M, Milos M, Milos M, Jurin M. The antitumor activity of thymoquinone and thymohydroquinone in vitro and in vivo. Exp Oncol 2006; 28 : 220-4.

40. Mohamed HA, El-Sayed IH, Moawad M. Protective effect of Nigella sativia seeds against dimethylaminoazobenzene
(DAB) induced liver carcinogenesis. Nature and Science 2010; 8: 80-7.

41. Mabrouk GM, Moselhy SS, Zohny SF, Ali EM, Helal TE, Amin AA. Inhibition of methylnitrosourea (MNU) induced oxidative stress and carcinogenesis by orally administered bee honey and Nigella grains in Sprague Dawely rats. J Exp Clin Cancer Res 2002; 21: 341-6.

42. Ilhan A, Gurel A, Armutcu F, Kamisli S, Iraz M. Antiepileptogenic and antioxidant effects of Nigella sativa oil against pentylenetetrazol-induced kindling in mice. Neuropharmacology 2005; 49: 456-64.

43. Mariod AA, Ibrahim RM, Ismail M, Ismail N. Antioxidant activity and phenolic content of phenolic rich fractions obtained from black cumin (Nigella sativa) seedcake. Food Chemistry 2009; 116: 306-12.

44. Houghton PJ, Zarka R, de las Heras B, Hoult JRS. Fixed oil of Nigella sativa and derived thymoquinone inhibit eicosanoid generation in leukocytes and membrane lipid peroxidation. Planta Med 1995; 61: 33-6.

45. Burits M, Bucar F. Antioxidant activity of Nigella sativa essential oil. Phytother Res 2000; 14: 323-8.

46. Nagi MN, Alam K, Badary OA, Al-Shabanah OA, Al-Sawaf HA, Al-Bekairi AM. Thymoquinone protects against carbon tetrachloride hepatotoxicity in mice via an antioxidant mechanism. Biochem Mol Biol Int 1999; 47: 153-9.

47. Türkdogan MK, Agaoglu Z, Yener Z, Sekeroglu R, Akkan HA, Avci ME. The role of antioxidant vitamins ( $C$ and $\mathrm{E}$ ), selenium and Nigella sativa in the prevention of liver fibrosis and cirrhosis in rabbits, new hopes. Dtscch Tierarzt Wschr 2000; 108: 71-3.

48. Mahmoud MR, El-Abhar HS, Saleh S. The effects of Nigella sativa oil against the liver damage induced by Schistosoma mansoni in mice. J Ethnopharmacol 2002; 79: $1-11$. 